\title{
Tutkimusmetodologia ja sen kehittäminen opettajan käyttöteorian ja opetuksen välisen suhteen tutkimuksessa
}

\author{
Katri Aaltonen \& Harri Pitkäniemi
}

Tutkijat ovat rakentaneet opettajan ajattelun ja opetuksen toteutuksen välistä suhdetta kuvaavaa käsitejärjestelmää. He ovat päätyneet neljään käsitteeseen, jotka hypoteettisessa mielessä ilmentävät ajattelun eritasoista dynamiikkaa ja sen monimutkaista luonnetta. Mikä on näiden tasojen keskinäinen vuorovaikutteisuus ja mitkä ja miten ne muodostavat käsitteellisessä ja dynaamisessa mielessä jatkumon?

Opettaja: Niin ... yllättävän paljon minä puhun ...Tästä videolta mie näenkin, että yllättävän paljon multa puhetta tuleekin ... (naurahtaa)... Mie oon aatellu, että minä en halluu hirveesti puhuu, mutta yllättävän paljon mie puhunkin - Mie en haluu esiintyä ... että minä haluun olla sellanen opettaja, joka niin kun ohjailen sitä oppimista ... Mulla ei oo semmosta esiintymisviettiä, että minä esitän teille tälläset hienot suunnitelmat ... että semmosta esiintymisviettiä ei oo ... Kyllähän minulta näköjään puhetta tullee aika nopeeseen tahtiin!

(katkelmatutkimusaineistosta, jossa haastattelun lähtökohtana on videonauhoitettu opetus; Aaltonen 2001, 8.)

Yllä olevassa haastattelukatkelmassa lähihoitajakoulutuksen opettaja ulkoistaa ajatteluaan omasta opettajuudestaan verraten sitä tunnin videoinnista näkyvään "todellisuuteen“. Haastattelukatkelma nostaa esiin monia kysymyksiä opettamisen taustatekijöistä ja voimista: Millainen mielikuva opettajalla on itsestään opettajana? Millai- sena opettajuus näyttäytyy tunnin toteutuksessa? Mitkä uskomukset ja käsitykset vaikuttavat valittuihin ratkaisuihin? Miten tietoinen opettaja itse on toimintansa taustatekijöistä?

Mm. tällaisia kysymyksiä tarkastellaan opettajan ajattelun tutkimuksessa, joka on nykyisin yksi elinvoimaisimmista opetuksen tutkimuksen traditioista. Keskeinen näkökulma opettajakognition tutkimuksessa onkin, miksi toimitaan niin kuin toimitaan. Toisaalta opettajan, ja varsinkaan eksperttiopettajan, toiminta ei aina ole tietoista, vaan se tapahtuu paljolti myös intuition varassa (ks. tark. Ropo 1991).

Opettajakognition tutkimuksen ensimmäisiin merkittäviin katsauksiin kuuluva julkaisu (Clark \& Peterson 1986) mallintaa alan tutkimusta kolmena erillisenä alueena: opettajan suunnittelun, interaktiivisen ajattelun ja nk. implisiittisten teorioiden tutkimuksena. Em. mallissa ajattelupro- 
sesseja on jäsennetty myös ajallisesti pre-, interja postaktiivisina vaiheina eli opetustilannetta edeltävänä suunnitteluna, opetustilanteen aikaisena ajatteluna ja päätöksentekona sekä opetustapahtuman jälkeisenä reflektiona. Edelleenkin näitä vaiheita tutkitaan myös erillisinä ilmiöinä, mutta nykyisin deskriptiiviset laadulliset tutkimukset eivät edusta opettajakognitiotutkimuksen kärkeä: uusien käsitteiden identifioimiseen ja nimeämiseen keskittyvää kuivailevaa tutkimusta on jo tehty riittävästi. Sen sijaan hajanaisen ja monenkirjavan käsiteviidakon selkiyttämiseksi ja kokonaiskäsityksen saamiseksi tarvittaisiin nykyistä enemmän teoreettista käsiteanalyysiä, empiirisiin tutkimuksiin perustuvia meta-analyysejä ja ylipäätään erilaisiin metodologioihin perustuvia tutkimussynteesejä. Mutta tarvetta olisi myös sellaisiin laaja-alaisiin tutkimuksiin, joiden avulla voitaisiin ymmärtää opettajan tietämyksen, tilannekohtaisen harkinnan ja suunnittelun merkitystä opetuksen ja oppimisen kokonaisuudessa.

Etenkin uudemmassa kognitiotutkimuksessa opettajan tieto ja tietämys ovat keskeinen tutkimuskohde. Tähän kuuluvat $\mathrm{mm}$. opettajan tiedon kategorioiden (esim. Shulman 1986) ja sen ominaispiirteiden tutkimus (esim. Clandinin \& Connelly 1991; Elbaz 1991; Zanting, Verloop, Vermunt \& van Driel 1998). Nykyisin tunnustetaan myös käyttötiedon verbalisoimisen merkitys opettajan ammatillisessa kehittymisessä ja korostetaan opettajan oman roolin merkitystä tietämyksen ja toiminnan reflektoinnissa (esim. Lyons, Freitag \& Hewson 1997; Ritchie 1999). Tutkimusta, joka valottaa linkkiä tiedon, ajattelun, toiminnan ja opetusvaikutusten välillä, tarvitaan siis myös opettajan professionaalisen kehittymisen kannalta. Kun tietoisuus ja ymmärrys omasta käyttötiedosta lisääntyy, opettaja tutkii sen tarkoituksenmukaisuutta ja ajattelee sitä uusista näkökulmista. Reflektion "rethink“" -prosessiin liittyykin aikaisemman ristiriitaisen tietämyksen esiintuominen, kyseenalaistaminen, pyrkimys siitä luopumiseen ja toiminnan muuntamiseen. Käyttöteorian artikuloimisen ja tietoiseksi tekemisen vaikeus on kuitenkin havaittu usein empiirisissä tutkimuksissa. Oman tietämyksen ja opettamisen ehkä tiedostamattomien itsestäänselvyyksien ja rutiinien esiintuominen on

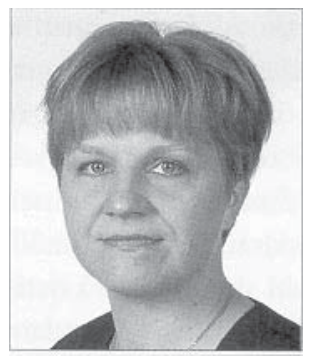

Katri Aaltonen

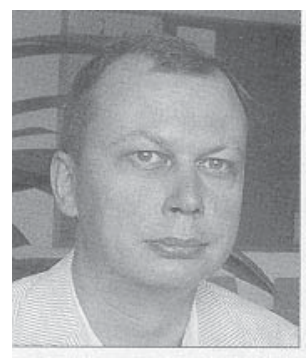

Harri Pitkäniemi

kokeneillekin opettajille hankalaa, eivätkä he ole tottuneet sitä tekemään. (Brown \& McIntyre 1993; Cornett, Yeotis \& Terwilliger 1990; Lyons ym.1997; Zanting ym. 1998.) Tämän vuoksi on tutkimustilanteissa opettajalle tarjottava reflektioon myös "välineitä“, joiden avulla toiminnan pohdinta kiinnittyy konkreettisiin tuntitilanteisiin, tavoitteisiin ja materiaaleihin eikä perustu pelkkiin koetun muistikuviin (ks. myös Atjonen 1995; 1996; Kansanen 1993).

Erilaisista lähtökohdista toteutetut tutkimusasetelmat ovat johtaneet tietoa kuvaavien käsitteiden runsauteen ja jopa osin tai kokonaan päällekkäisiin tutkimuskäsitteisiin (Aaltonen \& Pitkäniemi 2001). Pedagogisen interaktion näkökulmasta opettajan tietämystä kuvaavat tutkimukset tuovat kuitenkin esille vain yhden osakokonaisuuden. Keskeinen metodologinen kysymys ja ongelma on, miten tietämys välittyy opettajan ajattelusta toimintaan ja millä käsitteillä tietoa ja toimintaa sekä niiden välistä suhdetta voidaan kuvata. Aikaisemman katsauksemme perusteella katsomme, että opettajan ajattelun tutkimustraditiossa ei ole tarpeeksi kiinnitetty huomiota eri opettajakognitiivisten käsitteiden välisiin yhteyksiin. Edelleen on varsin hankalaa 
hahmottaa sitä, mikä on näiden erilaisten kognitio-käsitteiden kokonaisvaltainen suhde opetuksen toteutukseen. Yhteinen teesimme kuitenkin on, että sekä (a) opetuksen tutkimuksen teoreettinen, ilmiön ymmärtämisen taso että (b) opetuksen tutkimuksen käytännöllinen taso (so. kasvatuksellisen tietämyksen käyttäjät ja hyödyntäjät) voisivat kehittyä ja saada enemmän irti tutkimuksesta, joka nykyistä paremmin suhteuttaisi opettajakognition sisäisiä (esim. opettajan tieto, suunnittelu ja opetuksenaikainen ajattelu) käsitteitä ja niiden dynaamista yhteyttä toimintaan.

Tässä artikkelissa keskitymme tarkastelemaan sellaisia metodologisia kysymyksiä, jotka liittyvät opettajan ajattelun ja toiminnan välisten yhteyksien tutkimukseen. Aluksi esittelemme käsitejärjestelmän, joka on kuvattu ja perusteltu yksityiskohtaisemmin toisaalla (Aaltonen \& Pitkäniemi 2001). Tämä laaja-alainen käsitejärjestelmä on sinällään paradigmaattinen ja metodologinen valinta. Sen jälkeen luodaan katsaus aikaisemmissa empiirisissä opettajakognitio-tutkimuksissa käytettyihin aineistonhankintamenetelmiin. Työskentelymme tutkimusmetodologisena kehittelytavoitteena on rakentaa tutkimusasetelma, joka ottaa huomioon opettajan ajattelun ja toiminnan välisen suhteen myös aineistonhankintaprosesseissa. Tuohon asetelmaan sisältyvät (1) opettajan käyttöteorian ja suunnittelua kuvaavan skriptin (preaktiivinen vaihe), (2) interaktiivisen ajattelun ja tuntitilanteessa toimintaohjeena olevan agendan sekä (3) toiminnan reflektoinnin (postaktiivinen vaihe) tutkiminen aina kulloinkin mielekkäimmillä aineistonkeruumenetelmillä.

\section{Ehdotus käsitejärjestelmäksi}

$\mathrm{O}^{\prime}$ lemme aikaisemmin kirjoittaneet opettajakognitiota tarkastelevan katsauksen, jonka tavoitteena oli olemassa olevaan tutkimustietoon nojautuen rakentaa opettajan ajattelun ja opetustoteutuksen välistä suhdetta kuvaava käsitejärjestelmä (Aaltonen \& Pitkäniemi 2001). Päädyimme työssämme neljään käsitteeseen, jotka analyysimme mukaan voisivat hypoteettisessa mielessä ilmentää ajattelun eritasoista dynamiikkaa ja kompleksista luonnetta: (1) opettajan käyttöteoria(t), (2) skripti ("tunnin käsikirjoitus"), (3) agenda (tunnilla toteutuva, "eletty" lähisuunnitelma) ja (4) interaktiivinen ajattelu ("tässä ja nyt" -ajattelu opetustapahtumassa). Näiden lisäksi tulee luonnollisesti opettajan toimintaa kuvaava elementti, itse opetuksen toteutus. Pyrimme kytkemään yhteen sellaiset käsitteet, joilla on relaatiotarkasteluun sopiva vuorovaikutteinen luonne ja jotka näin ollen käsitteellisessä ja dynaamisessa mielessä muodostavat elimellisen jatkumon.

Käsitejärjestelmämme abstraktisin ja laajin opetuksen toteutusta viitekehystävä opettajakognition osatekijä on opettajan käyttöteoria. Se on opettajan henkilökohtainen tietämystä ja uskomuksia koskeva järjestelmä "hyvästä “ opetuksesta, jonka on useissa tutkimuksissa havaittu vaikuttavan siihen, millaiseksi opetustoteutus todellisuudessa muotoutuu ja millaisia mahdollisuuksia se tarjoaa oppijoiden oppimiselle (esim. McRobbie \& Tobin 1997; Moallem 1997; Ritchie 1999; Tobin \& Tippins 1996). Koska opettaja myös oppii opetuskokemustensa avulla, voidaan käyttöteoriaa pitää yleensä aina "testattuna“, käytäntöön sopivana, ”toimivana“ ja itseään vahvistavana teoriana - opettaja uskoo sellaisiin opetusta ohjaaviin periaatteisiin, jotka toimivat myös käytännössä. Käyttöteoria onkin sekä realistinen että toisaalta toimintapyrkimyksiä suuntaava ideaalikehikko. Opettajalla on ihanteita ja tavoitteita, joita hän haluaa opetuksessaan toteuttaa. Luonnollisesti hän tarvitsee tietoa myös todellisista "välineistä“, joiden avulla tämä teoria saadaan elämään.

Empiirisissä tutkimuksissa "opettajan tietoa" on kuvattu erilaisissa konteksteissa, aina opettajaopiskelijoista akateemisen opettajiin, ja monilla muillakin käsitteillä, kuten esimerkiksi käyttötietona, praktisena tietämyksenä, implisiittisinä ja subjektiivisina teorioina tai sisäisinä malleina (esim. suomalaisessa koulutuksessa: Husu 2002; Kansanen, Tirri, Meri, Krokfors, Husu, Jyrhämä 2000; Kosunen 1994; Niikko 1999; Tirri, Husu, \& Kansanen 1999; Tornberg 2000). Aikaisempien empiiristen tutkimusten perusteella opet- 
tajan henkilökohtaista ja kokemuksellista tietämystä voitaneenkin pitää osittain sanattomana, vaikeasti artikuloitavana ja monipuolisena tietona, joka liittyy oppilaisiin, opetusmenetelmiin, luokan hallintaan, koulun sosiaaliseen rakenteeseen, oppiainekseen, kehityspsykologiseen ajatteluun sekä oppimisteoreettiseen ja yhteiskunnalliseen ajatteluun (esim. Clandinin \& Connelly 1991; Mitchell 1994; Zanting ym. 1998). Toisaalta eri opettajien välillä on varsin suuri diversiteetti tiedon lajien ja painotusten suhteen. Esimerkiksi Meijerin, Verloopin ja Beijaardin (1999) lukemisen ymmärtämisen kontekstissa suoritettu tutkimus toi esiin opettajakohtaiset erot: he orientoituivat opetusajattelussaan siten, että mm. oppiaineeseen, opiskelijaan tai opiskelijan oppimiseen ja ymmärtämiseen liittyvä ajattelu painottui muita orientaatioalueita enemmän.

Käsitejärjestelmämme astetta konkreettisempi opettajakognition osatekijä on skripti. Se on kokonaisuus, joka sisältää näkemyksen tai mielikuvan tietyn oppimistavoitteen saavuttamiseen liittyvistä opetusjärjestelyistä, opetusmenetelmistä, materiaaleista jne. (ks. tark. Putnam 1987). Skripti on siten eräänlainen käsikirjoitus tunnin kulusta. Sen kautta opettaja työstää mielessään tai kirjallisesti menetelmiä ja aktiviteetteja, joiden avulla hän uskoo saavuttavansa opetuksen tavoitteet. Näin skripti toimii ajattelun ja toiminnan suhdetta kuvaavassa kokonaisjärjestelmässämme "välikäsitteenä“, jolla opettaja operationaalistaa abstraktia käyttöteoriaansa tunnin valmisteluun. Ehkäpä opetuksen suunnittelutyö onkin usein juuri "opetuspakettien“, kokonaisuuksien, käsikirjoitusten "näkymätöntä“ laatimista tai valitsemista oppituntia varten. Empiirisissä tutkimuksissa skriptiä yleisempi on kuitenkin ollut pedagogisen sisältötiedon käsite (Shulman 1986), vaikka se tuleekin määritelmällisesti varsin lähelle skriptiä. Myös pedagogisella sisältötiedolla tarkoitetaan tietyn sisältöalueen opettamiseen liittyvää tietämystä eli ko. aiheeseen spesifioitua "yhdistelmää“" substanssitiedosta ja yleisestä pedagogisesta tiedosta.

Näitä etukäteen työstettyjä "käsikirjoituksia“ opettaja voi harvoin toteuttaa sellaisenaan. Ope- tuksen interaktiotilanteessa kokenut opettaja muuntaakin suunnitelmiaan joustavasti (Brown \& McIntyre 1993; Moallem 1997; Westerman 1991) eli "päivittää“ skriptiään. Tämä ei kuitenkaan tarkoita, etteikö suunnitelmilla ja käsikirjoituksilla olisi erittäin keskeistä merkitystä opetustapahtuman ohjaamisessa. Mutta mikä sitten saa aikaa muutoksen ennakkosuunnitelmassa? Miten skriptin "päivittäminen" tapahtuu? Tuntityöskentelyssään opettaja tarvitsee myös ns. lähisuunnitelmia tai operationaalisia työohjelmia, agendoja, joiden kautta suunnitelmien on havaittu välittyvän opetustoteutukseen (Borko \& Livingston 1989). Näin ollen agenda voidaan määritellä toiminnallisena ja konkreettisena, tunnin interaktiivisessa vaiheessa "opettajan päässä olevana toiminta- tai työohjelmana“, joka dynaamisena rakenteena muuttuu tunnin kuluessa, kun hän vastaanottaa uutta tietoa opiskelijasta ja toisaalta nojautuu aikaisempaan tietoonsa (Leinhardt \& Greeno 1986; Putnam 1987).

Tuntitilanteissa opiskelijoilta vastaanotettujen vihjeiden ja opiskelijaa koskevan tiedon tärkeydestä huolimatta ennakkoon suunnitellun skriptin on havaittu olevan voimakkaasti tunnin toteutukseen vaikuttava tekijä (Irby 1992; Putnam 1987). Esimerkiksi Putnamin tutkimustulokset osoittivat, ettei opiskelijoilta vastaanotettujen vihjeiden diagnoosi ollut edes eksperttiopettajien ensisijainen tavoite matematiikan oppimisen ohjaustilanteissa. Tutkimuksen opettajat etenivät opettamisessaan ennalta suunnitellun esitystavan mukaisesti ja tekivät vain vähäisiä muutoksia opiskelijoilta vastaanottamiensa vihjeiden perusteella. Etukäteissuunnitelmien joustavassa muuntamisessa on havaittu eroja myös noviisija eksperttiopettajien välillä (esim. Cleary 1993; Westerman 1991).

Aikaisemmissa tutkimuksissa voidaan erottaa myös käsite, joka selkeästi pyrkii keskittymään spontaaniin ja tilanteissa viriävään opettajan "tässä ja nyt" -ajatteluun. Tällöin puhutaan opetuksenaikaisesta ajattelusta, nk. interaktiivisesta ajattelusta (esim. Marland \& Osborne 1990; Mitchell \& Marland 1989; Pitkäniemi 1998). Opetuksensa tiimellyksessä opettaja tulkitsee vastaanottamiaan opiskelijavihjeitä opetustavoitteidensa, aikaisem- 
man tietämyksensä ja kokemuksensa pohjalta, arvioi omaa suoriutumistaan, harkitsee vaihtoehtoisia ratkaisuja ja tekee nopeita päätöksiä tunnin etenemisestä. Kaiken kaikkiaan kiinnostus interaktiivista ajattelua kohtaan on ollut vilkasta ja empiirinen tutkimus onkin tuottanut kuvauksia erilaisista "tässä ja nyt" -ajattelun malleista ja niiden sisältöalueista. Lisäksi interaktiivista ajattelua tutkimalla on voitu selvittää, ohjaavatko opettajan käyttöteoriat tietoisella tasolla hänen opettamistaan ja mikä osuus puolestaan automatisoituneilla rutiineilla ja tiedostamattomilla valinnoilla on käyttöteorioita heijastavassa toiminnassa.

Käsitejärjestelmämme kolmeen käsitteeseen käyttöteoriaan, skriptiin ja agendaan - liittyy kaikkiin selkeä tulevaisuutta hahmottava perspektiivi. Perspektiivit ovat kuitenkin sekä laadullisesti että ajallisesti eritasoisia, vaikka tietyllä tavalla nämä käsitteet kimppuuntuvatkin myös yhdeksi kokonaisuudeksi, opettajan kognitioksi, jossa dynaamiset ja moninaiset vuorovaikutussuhteet ovat toiminnan perusta. Toisaalta nämä eri tasoiset "suunnitelmat" eletään läpi eli opetus toteutetaan niiden avulla, ja toteutus käynnistää tarvittaessa em. osatekijöiden uudelleenmuokkauksen tai vähintäänkin vahvistamisen. Se edellyttää kuitenkin opettajan omaa tietoisuutta osatekijöiden olemassaolosta.

\section{Tiedonhankintamenetelmien käyttö alueen aikaisemmissa tutkimuksissa}

$\mathrm{O}$ pettajan ajattelun tutkimuksessa ovat laadul liset tutkimusasetelmat olleet vallitsevia, vaikkakin mukaan mahtuu muutamia melko tuoreita kvantitatiivisia tutkimuksia (mm. Gatbonton 1999; Meijer 2001) ja molempia menetelmiä yhdistäviä tutkimuksia (mm. Kosunen 1994; Tornberg 2000). Aineistonhankintamenetelmiltään aikaisemmat laadulliset tutkimukset ovat kuitenkin hyvin yhteneväisiä: useimmiten on käytetty opetustilannetta edeltäviä ja/tai sitä seuraavia haastatteluja, oppituntien observointeja ja videointeja sekä stimulated recall -haastatteluja (taulukko 1).

Hahmotettaessa opettajan ajattelua ja toimintaa käyttöteorian, eritasoisten suunnitelmien ja interaktiivisen ajattelun perusteella on myös aineistonhankinnassa otettava huomioon ajattelun ja toiminnan eri vaiheet. Tutkimusasetelmallisesti ongelmallista lieneekin se, miten jäljitetään opettajan ajattelun ja toiminnan syklisyys sekä pre-,interja postaktiivisten vaiheiden toisiinsa kietoutuneisuus. Kun ajattelun ja toiminnan suhdetta kuvataan käsitteellisenä relaatioketjuna, ei välittömästi tule esille se, miten toteutuneen toiminnan reflektion tulisi johtaa käyttöteorian uudelleen ajattelemisen ("rethink") ja uudelleen rakentamisen ("rebuild") -prosesseihin ja edelleen kehittyneempään toimintaan.

Esittämämme käsitejärjestelmän seuraavat osittaissuhteet nousevatkin tutkimusmenetelmällisesti keskeisiksi haasteiksi:

$1 \begin{aligned} & \text { Opettajan käyttöteorian ja opetustoteutuk- } \\ & \text { sen välinen suhde. Miten osittain sanaton ja }\end{aligned}$ vaikeasti artikuloitavissa oleva käyttöteoria tehdään eksplisiittiseksi? Miten sen ilmeneminen validoidaan opetustoteutuksessa?

Käyttöteorian ja skriptin suhde. Miten jäljiL tetään todellinen opetuksen suunnitteluprosessi varsinkin kokeneilla opettajilla, joilla suunnittelu tapahtuu usein mentaalisena tunnin visualisointina sekä ajallisesti ja paikallisesti hyvin vaihtelevasti?

3 Käyttöteorian, skriptin ja interaktiivisen ajat3 telun suhde. Miten jäljitetään todellinen opetuksenaikainen ajattelu ja päätöksenteko, monimuotoisen toimintakontekstin lukeminen ja aikaisempien suunnitelmien päivittäminen eli agendan "eläminen" opetuksen todellisuudessa? 1 Opetustoteutuksen ja käyttöteorian "feed4 back"-suhde. Miten postaktiivisessa vaiheessa mahdollistetaan toteutuneen toiminnan arvioiminen, kyseenalaistaminen ja uusien vaihtoehtojen pohtiminen (reflection-on-action, reflection-for-action) niin, että se paljastaa opetuksen itsestäänselvyydet ja johtaa käyttöteorian uudelleenrakentamiseen?

Näihin haasteisiin voidaan hakea vastausta aikaisempien empiiristen tutkimusten perusteella konstruoimalla niiden pohjalta sellaisia tutkimusasetelmakokonaisuuksia, jotka mahdollistavat 
Taulukko 1. Opettajan ajattelun ja opetustotoutuksen suhteen esiin tuomisessa käytettyjä aineistonhankintamenetelmiä

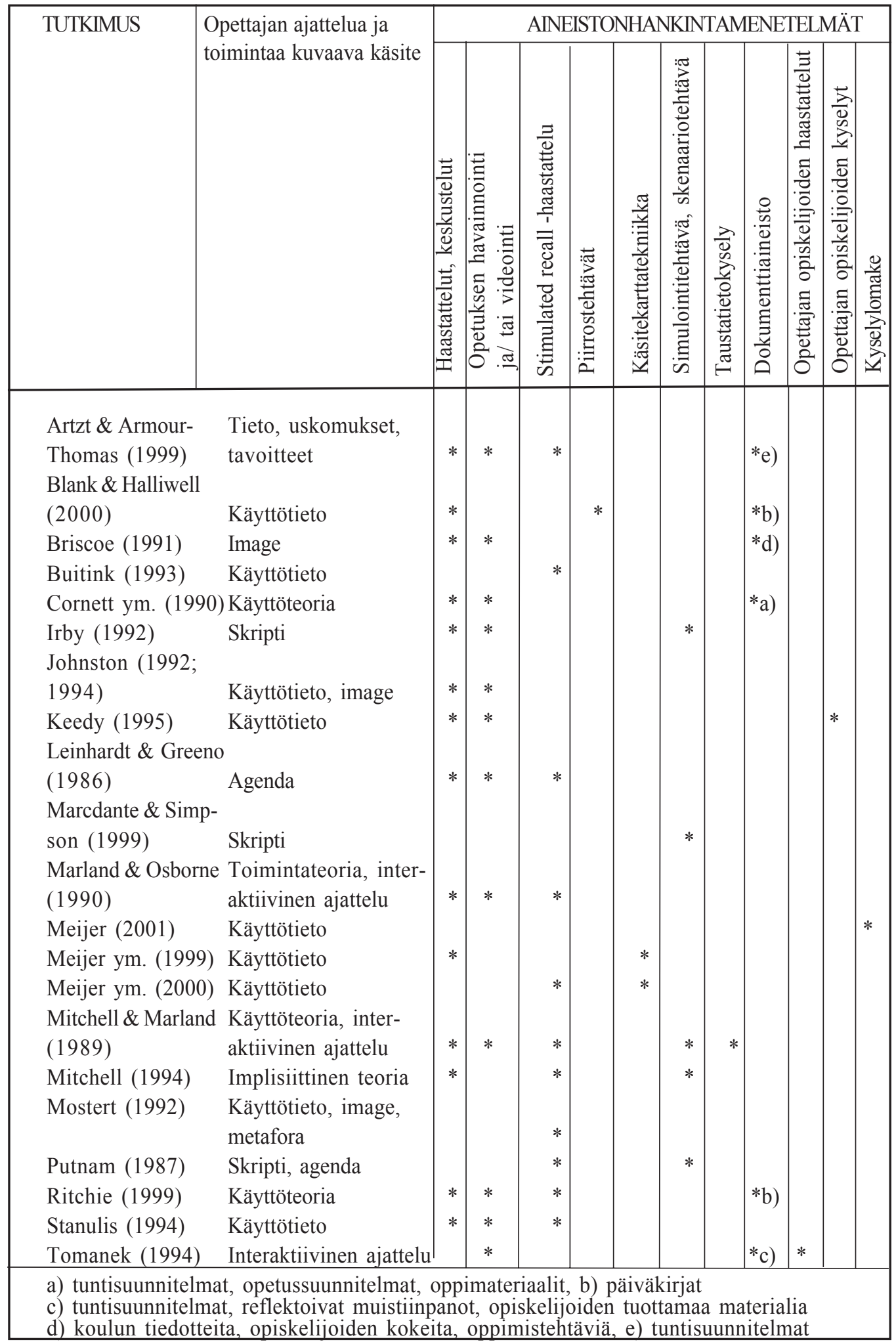


opettajan ajattelun ja toiminnan kartoittamisen esittämämme käsitejärjestelmän mukaisesti.

Useimmissa tutkimuksissa käyttöteoriaa on eksplikoitu avoimien ja/tai teemahaastattelujen perusteella, joita on sisällytetty tutkimusprosessin eri vaiheisiin (taulukko 1). Esimerkiksi Johnston (1994) suoritti opettajaopiskelijoita koskevassa tutkimuksessaan useita lyhyitä (25-45 minuutin) haastatteluja, jotka fokusoituivat opiskelijoiden opettamista ja opettajuutta koskeviin näkemyksiin. Haastattelut ovat usein jopa keskustelunomaisia (informal conversation), joissa avoimilla kysymyksillä ja muutaman tutkittavaa ilmiötä kuvaavan ydinteeman avulla haetaan käyttötietoa ja -teoriaa (esim. Black \& Halliwell 2000; Cornett ym.1990; Johnston 1994; Meijer ym. 1999; Ritchie 1999). Erilaisiin haastatteluasetelmiin on myös trianguloitu muita aineistonhankintamenetelmiä, mm. käsitekarttojen konstruointia ja niiden kommentointia (esim. Meijer ym.1999; Meijer, Zanting \& Verloop 2000). Käyttötiedon kaltaisen tiedon kommunikoimista on usein pidetty vaikeana formaalin kielen avulla ja esimerkiksi Black ja Halliwell (2000) määrittivät sitä myös opettajien tekemien piirrosten ja niihin liittyvien vertauskuvallisten metaforien perusteella. Käyttötiedon kuvaaminen ja jopa kehittäminen metaforien ja mielikuvien (imagien) avulla on osoittanut käyttökelpoisuutensa muissakin tutkimuksissa (esim. Johnston 1992; 1994; Tobin \& Tippins 1996; Ritchie 1994). Imaget ja metaforat ovat myös osa laajaa narratiivista tutkimusta, jossa opettaja "tarinan kertojana" ilmaisee menneisyyteen, nykyhetkeen ja tulevaisuuteen sitoutunutta tietämystään ja kokemuksiaan omalla "äänellään", omin sanoin (esim. Clandinin \& Connelly 1995; Connelly \& Clandinin 1986; Elbaz 1991; Gudmundsdottir 1991; Husu 2002; Tirri ym. 1999).

Oma kysymyksensä tutkimusasetelmissa näyttää olevan se, miten osoitetaan opettajan puheessaan ilmaiseman käyttöteorian yhteys opetuksen toteutukseen. "It is easy to find teachers who talk a good job without necessarily doing a good job“ -kommentti Desforgesin (1995) tutkimuksesta kuvaakin osuvasti ongelmaa siitä, mikä on puheen ja todellisen toiminnan suhde. Useim- miten opettajan haastattelussa esiintuomaa käyttöteoriaa validoidaan opetustoteutuksen havainnoinnin perusteella. Toisaalta observointiaineistojen pohjalta on luotu ajattelun ja käyttöteorian kontekstia, ja lisävalaistusta siihen on tuotu myös erilaisilla dokumenttiaineistoilla, kuten tunti- ja opetussuunnitelmilla, päiväkirjoilla, reflektiotehtävillä, opetusmateriaaleilla (taulukko 1).

Harvemmin käytetty toimintatapa opettajan puheessaan esiintuoman käyttöteorian validoinnissa on käyttää opiskelijoita tulosten arvioijina (esim. Keedy 1995). Keedyn oppijakeskeistä pedagogiikkaa koskevan käyttötiedon tutkimuksessa tutkija määritti ensin käyttötiedon piirteet opettajahaastattelujen pohjalta ja testasi tuntiobservoinneilla, löytyikö opetustoteutuksesta tukea esitetylle käyttötiedolle. Vain ne käyttötiedon piirteet, jotka tutkija havainnoi myös opettajien toiminnasta, "hyväksyttiin jatkoon". Seuraavaksi tutkija validoi jatkoon päässeet käyttötiedon piirteet opiskelijakyselyn avulla, jossa kunkin opettajan omat opiskelijat vastasivat kyllä/ei -kysymyksiin sen pohjalta, kuvasiko väittämä heidän mielestään opettajan toimintaa vai ei. Vain sellaiset käyttötiedon piirteet, jotka kaksi kolmasosaa opiskelijoista hyväksyi, otettiin mukaan oppijakeskeistä pedagogiikkaa kuvaavaan käyttötietoon.

Tutkimusmenetelmällisesti toinen haasteellinen tehtävä on jäljittää, miten käyttötieto välittyy (tai ei välity) opetuksen ennakko- ja tunnin aikana muuttuviin suunnitelmiin. Haasteelliseksi tämän tekee se, että varsinkaan kokeneiden opettajien suunnittelu ei tapahdu aina keskitetysti tiettynä tuntia edeltävänä hetkenä. Luonnollisen suunnitteluprosessin esiin tuominen voikin olla vaikeaa, vaikka suunnitteluhaastattelut toteutettaisiin ennen opetustapahtumaa esimerkiksi ääneen ajattelun menetelmällä (mm. Irby 1992; Kosunen 1994), kuvitteellisten skenaariotehtävien (mm. Mitchell \& Marland 1989) ja simuloitujen kirjallisten tai tietokoneavusteiset suunnittelutehtävien avulla (mm. Irby 1992; Leinhardt \& Greeno 1986; Marcdante \& Simpson 1999) (taulukko 1). Suunnittelua on jäljitetty myös kvantitatiivisilla kyselylomakkeilla (esim. Tornberg 
2000) ja tunnin jälkeen "post" -haastatteluissa. Mm. Artztin ja Armour-Thomasin (1999) tutkimuksessa opettajat raportoivat preaktiivista ajattelua - tuntisuunnittelun sisältöjä, kontekstia ja siihen vaikuttaneita tekijöitä - vasta opetustilanteen jälkeen tapahtuneessa haastattelussa.

Edellä kuvatut aineistonhankintamenetelmät ovat esimerkkejä pääasiassa opettajan ajattelun ja toiminnan osarelaatioiden - parin käsitteen keskinäisen suhteen - paljastamisesta. Kokonaisrelaation selvittäminen edellyttää kuitenkin aineistonhankinnassa prosessimaisuutta, jolloin ajattelua jäljitetään niin pre- ja postaktiivisessa kuin interaktiivisessa vaiheessa. Tällöin tutkimusasetelmaan kuuluu:

1 käyttöteoriaa, suunnittelutottumuksia ja telua kartoittava haastattelu,

2 opetuksen toteutukseen keskittyvä obser2 vointi ja suunnitelmien toteuttamista ja interaktivista ajattelua kartoittava SR-haastattelu ${ }^{1}$ ja

3 postaktiiviseen pohdintaan kohdentuva

Myös tällaisia laajempialaisia tutkimusasetelmia löytyy aikaisemmista empiirisistä tutkimuksista. Esimerkiksi Borkon ja Livingstonin (1989), Westermanin (1991) ja Moallemin (1998) noviisi- ja eksperttiopettajia koskevat tutkimusasetelmat muodostuivat kolmivaiheisiksi suunnittelu/opetustoteutus/reflektio -sykleiksi, joissa opetusta edeltävissä haastatteluissa kartoitettiin opettajien suunnittelutottumuksia ja siihen vaikuttavia tekijöitä. Opetustoteutuksen observointia seuranneet haastattelut keskittyivät toiminnan reflektioon eli tunnin keskeisten piirteiden jäljittämiseen, odottamattomiin tapahtumiin sekä suunnitelmien muutoksiin ja perusteluihin.

Aikaisempien empiiristen tutkimusten perusteella tulee esille opetuksen videointiin ja sen katseluun liittyvän tutkimusasetelman monipuolisuus aineistonhankinnassa. SR-haastattelua käytetään pääsääntöisesti opetustilanteiden aikaisen ajattelun raportoimisessa, jolloin video toimii ajattelun mieleen palauttamisen stimuloijana ja auttaa opettajaa "elämään uudelleen“ tunnin tapahtumat. Ko. menetelmä on osoittautunut hyö- dylliseksi myös sekä käyttötiedon eksplikoimisessa (esim. Buitink 1993; Calderhead 1981; Marland \& Osborne 1990; Meijer ym. 2000) että postaktiivisen ajattelun, reflektion, joskus jopa spontaanissa esiintuomisessa (esim. Stanulis 1994) (taulukko 1). SR-haastattelutilanne näyttääkin sopivan lähes kaikkiin em. kolmiportaisen aineistonhankinnan vaiheisiin: sen alkuun voidaan sijoittaa erillinen suunnittelua retrospektiivisesti kartoittava haastatteluosuus ja itse videon katseluvaiheessa opettaja raportoi sekä inter- että postaktiivista ajattelua.

SR-aineiston monimuotoisuus voi olla myös tutkimuksen kompastuskivi, ellei tutkija ole tietoinen opettajan ajattelun fokusoitumisen mahdollisuuksista. SR-haastattelussa opettaja joko spontaanisti tai tutkijan ohjaamana:

(1) raportoi tuntitilanteen aikaista interaktiivista opetustilanneajatteluaan (interactive thoughts) eli paljastaa opetustoteutukseen vaikuttaneita tekijöitä, päätöksentekoa ja tunnin aikaista reflektiota (reflection-in-action),

(2) raportoi videon katselun stimuloimia ajatuksiaan (post-lesson thoughts), jotka syntyvät haastattelutilanteessa ja ovat näin ei-interaktiivista aineistoa (non-interactive thoughts) eli opettaja tuo julki ko. tuntitilanteeseen sidottua käyttötietoa sekä toiminnan ja sen perusteiden reflektiota (reflection-on-action, reflection-foraction) tai

(3) raportoi videon katselun stimuloimia eiinteraktiivisia, yleisiä opettamiseen ja oppimiseen liittyviä uskomuksia ja väittämiä eli tuo julki käyttötiedon yleisiä elementtejä ja opettamisen kontekstia sekä niiden reflektiota (reflection-onaction, reflection-for-action). (Marland 1986; Marland \& Osborne 1990; Yinger 1986; ks. myös Aaltonen 2001.)

Haastattelun tuottamaa aineistoa interaktiivisen ajattelun kuvaajana on usein kyseenalaistettu (Calderhead 1996; Yinger 1986). Koska SR-menetelmä perustuu opettajan arviointeihin reflection-on-action -asetelmassa, pidetään sitä usein riittämättömänä ja harhaanjohtavana interaktiivisen ajattelun indikaattorina. Sen sijaan reflektiolle videoidut tuntitilanteet luovat kiinnittymispintaa ja niiden antamat uudet vihjeet ovat 
opettajalle ensiarvoisen tärkeitä ajattelun aktivoijia (esim. Aaltonen 2001; Stanulis 1994). Opettajan arvioidessa kokemaansa ja näkemäänsä opetustilannetta suhteessa sen tavoitteisiin, suunnitelmiin ja omaan käyttötietoonsa pre-, interja postaktiivinen ajattelu kietoutuvat toisiinsa vaikuttavaksi prosessiksi.

\section{Kehittämistarpeita opettajakognition ja opetuksen välisen suhteen tutkimuksessa}

$\mathrm{K}$ aiken kaikkiaan opettajakognition ja opetusdellisuuden välisen keskinäisen suhteen ymmärtäminen edellyttää käsitejärjestelmän riittävää teoreettista osuvuutta ja "peittävyyttä". Meillä tulee olla käytössä riittävän monipuolinen, mutta myös käsitteiden keskinäiseen systeemiin pohjautuva käsitekokoelma. Olemme päätyneet sekä aikaisempaan tutkimukseen porautuvan käsitteellisen analyysimme että toisaalta oman luovan kehittelytyömme perusteella siihen, että (1) käyttöteorian, (2) skriptin, (3) agendan ja (4) spontaanin opetustilanneajattelun sisältävä opetuskognition kokoelma mahdollistaa käsitteellisesti pätevän tutkimuksen suunnittelun.

Edelleen vaaditaan sitä, että tiedonhankintamenetelmiä sovelletaan ja käytetään tavalla, joka tuo kompleksisesta ajattelusta, päätöksistä, intuitiosta ja luokkahuonetapahtumista koostuvan kokonaisuuden pätevästi ja luotettavasti esiin. Tutkimuksen metodista diversiteettiä tulisikin laajentaa siten, että käyttöteoriaa tutkitaan kognitio- ja toteutusketjun eri kohdista. Esimerkiksi teemahaastattelulla, jota usein tutkimuksissa käytetään, ei aina saada totuudellista ja riittävän yksityiskohtaista käsitystä opettajan käyttöteoriasta. Subjektiivisille teorioille on tunnusomaista, että opettaja ei välttämättä tiedosta teorioitaan (tai yhtä suurempaa teoriakokoelmaansa). Toisinaan tutkimuksen käyttämä formaali kieli ei näytä toimivan opettajan teorian identifioimisessa: teoria saattaakin nousta esiin paremmin joitakin muita ilmiasuja hyödyntäen. Tutkijan pitää tiedostaa myös ne ongelmat, jotka liittyvät eksplisiittisen ja ilmoitetun teorian luotettavuuteen. Tutkimusmenetelmien kirjoa tulisikin laajentaa "epäsuorempiin" keinoihin. Tällaisina voidaan pitää esimerkiksi käsi- tekarttatekniikkaa, erilaisten dokumenttiaineistojen hyödyntämistä, opiskelijoiden haastattelua ja SR-aineiston analyysiin perustettavaa käsitystä opettajan käyttöteoriasta.

Käyttöteorian aineistonhankintaa voidaan parantaa myös useammilla rinnakkaisilla aineistonkeruutapahtumilla. Näin tavoitettaneen paremmin kokonaiskäsitys opettajan käyttöteorian ja tietämyksen kokonaislaajuudesta ja sen jäsentyneisyydestä. Ylipäätään erityyppiset aineistonhankintatekniikat soveltuvat ehkä huomattavasti käsitteellisesti laajemman ilmiökentän kuvaamiseen kuin on tähän asti osattu hyödyntää alan aikaisemmissa empiirisissä tutkimuksissa. Esimerkiksi SR -metodologiaa voidaan hyödyntää erittäin taitavasti, suunnitelmallisesti ja monipuolisesti. Sen avulla voidaan paljastaa sellaista käyttöteoriaa, jolla on suhteellisen välitön ja reaalinen yhteys opettajan opetustilanteessa tekemiin päätöksiin ja toiminnan perusteisiin. "Todellisten" tilanteiden lisäksi erilaiset simulointitilanteet tuottavat tutkijalle sopivaa aineistoa opetustilanneajattelun ja käyttöteorian välisen suhdemekanismin ymmärtämiseksi.

Opetuksen toteutuksen tutkimuksessa ei liikuta varsinaisesti opettajakognition alueella, mutta myös sen kautta saatua aineistoa voidaan käyttää opettajakognition eri käsitteiden epäsuoraan tutkimiseen. Observointiaineisto kertoo joka tapauksessa siitä, mitä opetuksessa tapahtui opettajan päätöksistä johtuen tai niistä huolimatta. Mutta sen avulla voidaan luoda kuvaa myös opettajan pyrkimyksistä, "teorioista", interaktiivisista päätöksistä ja intuitiivisesta ajattelusta. Erilaisia tiedonhankintamenetelmiä hyödyntäen voidaan siis tutkia sitä jännitettä, joka muodostuu pääkäsitteiden (kognitio, toimintakognitio ja opetustodellisuus) välille. Tuo jännite ja suhdetila on todennäköisesti joskus ristiriitainen ja toisinaan taasen hyvinkin sopusuhtainen kokonaisuus.

Tähän mennessä toteutettu opetuskognition ja -toteutuksen välinen tutkimus ja siihen perustuva teoria viestittää meille siitä, että opettajalla pitää olla kohtuullisen korkeatasoisia uskomuksia (vaatimuksia itselleen ja oppilailleen), riittä- 
västi pedagogista sisältötietoa (teorian operationalisointia varten) ja ylipäätään erilaisia opetuksen mentaalisia malleja, jotta hän pystyisi toteuttamaan opetusteoriaansa. Toisaalta - ja tämä on vähintään yhtä tärkeätä - hänen pitää myös pystyä lukemaan opetusympäristöön sisältyvää moninaista vihjeistöä. Tästä em. kokonaisuudesta syntyy monimutkainen ja vuorovaikutteinen kognition ja opetustoteutuksen välinen yhdistelmäkenttä, jonka sisältämiä teoreettisia ideaalivaihtoehtoja tulee suunnitella ja tutkia tulevissa tutkimuksissa myös empiirisesti.

\section{Lähteet}

AALTONEN, K. (2001) Use of the stimulated recall method as a reflective tool in eliciting practical knowledge of an experienced nursing teacher. Paper presented at the European Conference on Education Research (ECER), Lille, France, September 2001.

AALTONEN, K. \& Pitkäniemi, H. (2001) Opettajan ajattelun ja opetuksen toteutuksen välinen mysteeri: voidaanko se paljastaa? Kasvatus 32 (4), 402418.

ARTZT, A. F. \& Armour-Thomas, E. (1999) A cognitive model for examining teachers' instructional practice in mathematics: a guide for facilitating teacher reflection. Educational Studies in Mathematics 38, 211-234.

ATJONEN, P. (1995) Opetustapahtuman kuvaaminen didaktisessa opetuslaboratoriossa. Osa 2. Opettajan didaktisten ajattelu- ja toimintavalmiuksien kehittäminen. Oulun yliopiston Kajaanin opettajakoulutuslaitoksen julkaisuja. Sarja A: Tutkimuksia 8

ATJONEN, P. (1996) "Pitäs olla opella viis silimää" Video- ja observointimateriaali opettajaksi opiskelevan didaktisen ajattelun kehittämisessä. Kasvatus 27 (3), 228-239.

BLACK, A. L. \& Halliwell, G. (2000) Accessing practical knowledge: how? why? Teaching and Teacher Education 16, 103-115.

BORKO, H. \& Livingston, C. (1989) Cognition and improvisation: Differences in mathematics instruction by expert and novice teachers. American Educational Research Journal 26 (4), 473-498.

BRISCOE, C. (1991) The Dynamic Interaction Among Beliefs, Role Metaphors, and Teaching Practices: A Case Study of Teacher Change. Science Education 75 (2), 185-199.

BROWN, S. \& Mclntyre, D. (1993) Making sense of teaching. Buckingham: Open University Press.

BUITINK, J. (1993) Research on teacher thinking and implications for teacher training. European Journal of Teacher Education 16 (3), 195-203.

CALDERHEAD, J. (1981) Stimulated recall: A method for research on teaching. British Journal of Educational Psychology 51 (2), 211-217.

CALDERHEAD, J. (1996) Teachers: Beliefs and knowledge. Teoksessa: D. C. Berliner \& R. C. Calfee (toim.). Handbook of educational psychology. New York: Macmillan, 709-725.

CLANDININ, D. J. \& Connelly, F. M. (1991) Personal knowledge. Teoksessa: Lewy, A. (toim.) The International Ensyclopedia of Curriculum. Oxford: Pergamon Press, 128-131.

CLANDININ; D. J. \& Connelly, F. M. (1995) Teachers' professional knowledge landscape. Columbia University: Teacher College Press.

CLARK, C.M. \& Peterson, P.L. (1986) Teachers' thought processes. Teoksessa: Wittrock, M.C. (toim.) Handbook of research on teaching. Third edition. New York: Macmillan, 255-296.

CLEARY, M. J. (1993) Toward teaching expertise: The interactive decisions of school health student teachers. Health Educator 25 (1), 16-22.

CONNELLY, M. F. \& Clandinin, D. J. (1986) On Narrative Method, Personal Philosophy, and Narrative Unities in the Story of Teaching. Journal of Research in Science Teaching 23 (4), 293-310.

CORNETT, J. W., Yeotis, C., \& Terwilliger, L. (1990) Teacher personal practical theories and their influence upon teacher curricular and instructional actions: A case study of a secondary science teacher. Science Education 74 (5), 517-529.

DESFORGES, C. (1995) How does experience affect theoretical knowledge for teaching? Learning and Instruction 5, 386-400.

ELBAZ, F. (1991) Research on Teacher's Knowledge: The Evolution of a Discourse. Journal of Curriculum Studies 23 (1), 1-19.

GATBONTON, E. (1999) Investigating Experienced ESL teachers' pedagogical knowledge. The Modern Language Journal 83, 35-50.

GUDMUNDSDOTTIR, S. (1991) Story-maker, story-teller: narrative structures in curriculum. Journal of Curriculum Studies 23 (3), 207-218.

HUSU, J. (2002) Navigating through pedagogical practice. Teachers' epistemological stances towards pupils. Teoksessa: C. Sugrue \& C. Day (toim.) Developing teachers and teaching practice: International research perspectives. London: Routledge Falmer, 58-72.

IRBY, D. M. (1992) How attending physicians make instructional decisions when conducting teaching rounds. Academic Medicine 67 (10), 630-638.

JOHNSTON, S. (1992) Images: A Way of Understanding the Practical Knowledge of Student Teachers. Teaching and Teacher Education 8 (2), 123-136.

JOHNSTON, S. (1994) Conversations with student teachers - Enhancing the dialogue of learning to teach. Teaching and Teacher Education 10 (1), 71-82

KANSANEN, P. (1993) Onko pedagoginen ajattelu tutkimusta? Teoksessa: Ojanen, S. (toim.) Tutkiva opettaja. Opetus 21. vuosisadan ammattina. Helsingin yliopisto. Lahden tutkimus- ja koulutuskeskus. Oppimateriaaleja 21, 40-51.

KANSANEN, P., Tirri, K., Meri, M., Krokfors, L., Husu, J. \& Jyrhämä, R. (2000). Teachers' pedagogical think-ing. Theoretical landscapes, practical challenges. New York: Peter Lang.

KEEDY, J. L. (1995) Teacher practical knowledge in restructured high schools. Journal of Educational Research 89 (2), 76-89.

KOSUNEN, T. (1994) Luokanopettaja kirjoitetun ope- 
tussuunnitelman käyttäjänä ja kehittäjänä. Joensuun yliopisto. Kasvatustieteellisiä julkaisuja 20.

LEINHARDT, G. \& Greeno, J. G. (1986) The cognitive skill of teaching. Journal of Educational Psychology 78 (2), 75-95.

LYONS, L. L., Freitag, P. K. \& Hewson P. W. (1997) Dichotomy in Thinking, Dilemma in Action: Researcher and Teacher Perspectives on a Chemistry Practice. Journal of Research in Science Teaching 34 (3), 239-254.

MARCDANTE, K. W. \& Simpson, D. (1999) How pediatric educators know what to teach: The use of teaching scripts. Pediatrics 104 (1), 148-151.

MARLAND, P. (1986) Models of teachers' interactive thinking. Elementary School Journal 87 (2), 209226.

MARLAND, P. \& Osborne, B. (1990) Classroom theory, thinking, and action. Teaching and Teacher Education 6 (1), 93-109.

McROBBIE, C. \& Tobin, K. (1997) A Social Constructivist Perspective on Learning Environments. International Journal of Science Education 19 (2), 193208.

MEIJER, P. C. (2001) Similarities and differences in teachers' practical knowledge about teaching reading comprehension. Journal of Educational Research 94 (3), 171-185.

MEIJER, P.C., Verloop, N. \& Beijaard, D. (1999) Exploring language teachers' practical knowledge about teaching reading comprehension. Teaching and Teacher Education 15, 59-84.

MEIJER, P. C., Zanting, A. \& Verloop, N. (2000) How can student teachers elicit experienced teachers' practical knowledge? Tools, suggestions and significance. Paper presented at the European Conference on Education Research (ECER), Edinburgh, Scotland; September 2000.

MITCHELL, J. (1994) Teachers' Implicit Theories Concerning Questioning. British Educational Research Journal 20 (1), 69-83.

MITCHELL, J. \& Marland, P. (1989) Research on teacher thinking: The next phase. Teaching and Teacher Education 5 (2), 115-128.

MOALLEM, M. (1997) The content and nature of reflective teaching: A case of an expert middle school science teacher. Clearing House, 70 (3), 143-151.

MOALLEM, M. (1998) An expert teacher's thinking and teaching and instructional design models and principles: an ethnographic study. Educational Technology Research and Development 46 (2), 37-64.

MOSTERT, M. P. (1992) Personal Teaching: Puzzles, images, and stories for professional reform. Preventing School Failure, 36 (4), 16-20.

NIIKKO, A. (1999). Akateemisen opettajan tiedonalueista. Joensuun yliopisto. Kasvatustieteiden tiedekunnan tutkimuksia 77.

PITKÄNIEMI, H. (1998) Opettajiksi opiskelevien opetustilanneajattelun sisällöt ja oppitunnin toteutus. Helsingin yliopiston kasvatustieteen laitoksen tutkimuksia 162.

PUTNAM, R. T. (1987) Structuring and adjusting content for students: A study of live and simulated tutoring of addition. American Educational Research Journal 24 (1), 13-48.
RITCHIE, S. M. (1994) Metaphor as a Tool for Constructivist Science Teaching. International Journal of Science Education 16 (3), 293-303.

RITCHIE, S.M. (1999) The craft of intervention: A personal practical theory for a teacher's within-group interactions. Science Education 83 (2), 213-231.

ROPO, E. (1991) Opettajaeksperttiyden kehittyminen - tutkimustuloksia ja näkökulmia. Aikuiskasvatus 11 (3), 153-163.

SHULMAN, L. S. (1986) Those who understand: Knowledge growth in teaching. Educational Researcher 15 (2), 4-14.

STANULIS, R. N. (1994) Fading to a whisper: one mentor's story of sharing her wisdom. Journal of Teacher Education 45 (1), 31-39.

TIRRI, K., Husu, J. \& Kansanen, P. 1999. The epistemological stance between the knower and the known. Teaching and Teacher Education 15, 911922.

TOBIN, K. \& Tippins, D. J. (1996) Metaphors as seeds for conceptual change and the improvement of science teaching. Science Education 80 (6), 711730.

TOMANEK, D. (1994) A case of dilemmas: exploring my assumptions about teaching science. Science Education 78 (5), 399-414.

TORNBERG, A. (2000) Valistus on viritetty. Seurantatutkimus luokanopettajaksi opiskelevien suunnitteluorientaation, sisäisten mallien, opetustilanneajattelun ja refelktion kehityksestä. Acta Universitas Lapponiensis 35 .

WESTERMAN, D.A. (1991) Expert and Novice Teacher Decision making. Journal of Teacher Education 42 (4), 292-305.

YINGER, R. J. (1986) Examining thought in action: a theoretical and methodological critique of research on interactive teaching. Teaching and Teacher Education 2 (3), 263-282.

ZANTING, A., Verloop, N., Vermunt, J .D. \& van Driel, J. H. (1998) Explicating Practical Knowledge: an Extension of Mentor Teacher's Role. European Journal of Teacher Education 21 (1), 11-28.

\section{Viite}

1. SR-menetelmä/haastattelu tulee sanoista stimulated recall eli stimuloitu mieleenpalauttaminen. Siinä opettaja katsoo yhdessä haastattelijan kanssa oppituntinsa videointia ja yrittää palauttaa mieleensä tunnin aikaisia ajatuksiaan. Videolta näkyvien vihjeiden oletetaan toimivan muistin aktivoijina ja helpottavan ajatusten mieleenpalauttamista.

Artikkeli saapui toimitukseen 20.11.2001. Se hyväksyttiin julkaistavaksi toimituskunnan kokouksessa 5.6.2002. 